\title{
Optimising long-term countermeasure strategies for agricultural systems based on current management practices, environmental conditions and costs
}

\author{
C.A. Salt
}

Department of Environmental Science, University of Stirling, Stirling FK9 4LA, U.K.

\begin{abstract}
Farm-scale and catchment scale approaches to the implementation of Decision Support Systems (DSS) for post-emergency management of contaminated agricultural systems are presented. These are aimed at optimising the selection of countermeasures by integrating the needs of radiation protection with the constraints posed by agricultural management practices, environmental conditions and costs. The two approaches are iliustrated for an area of south-west Scotland dominated by livestock farming and their specific merits and limitations as well as those of DSS in general are summarised.
\end{abstract}

\section{INTRODUCTION}

Successful optimisation of countermeasures in agricultural systems should deliver not only the desired level of radiation protection but also seek to minimise social and economic costs. Such costs arise not only from the direct expenditure required to undertake the countermeasure but also where there is disuption to agricultural production or damage to the environment [1]. The optimisation should aim to dovetail the countermeasure with existing agricultural practices while at the same time taking into account any physical or chemical limitations posed by the local environment.

Very detailed farm-specific strategies give good local accuracy, but they are expensive and timeconsuming. The use of Geographic Information Systems allows an assessment of the influences of topography, land use and soil type and interactions between different countermeasures across a range of farm types, for example in a river catchment [2]. As part of the CESER (CountermeasuresEnvironmental and Socio-Economic Responses) project a farm-scale and a catchment-scale Decision Support System have been developed for long-term countermeasure implementation. Their capabilities and data requirements are illustrated for a case study area in Scotland. A range of countermeasures, aimed at reducing levels of radiocaesium and radiostrontium in food products, can be simultaneously evaluated in terms of their likely environmental, agricultural and economic impacts.

\section{THE FARM SCALE APPROACH}

The case study farm lies in the Glenstang Burn catchment in south-west Scotland. It is a 120 ha dairy arm split into $56 \%$ grazed grassland and $44 \%$ mowing grass for silage production. The 150 milking cows plus 40 heifers and some young cattle are housed for 6 months.

Figure 1 illustrates the countermeasure evaluation process using the CESER-DSS, an interactive PCbased expert system/decision support system. At the beginning of the countermeasure evaluation, the user has to choose a radionuclide deposition scenario and farm type (Fig. 2). This produces a list of basically suitable countermeasures, in this case 4:

Administer AFCF (ammonium-iron-hexacyanoferrate)

Feed calcium

Feed clean commercially available concentrate (to cover $80 \%$ of net energy intake)

Feed concentrate grown on farm (to cover $80 \%$ of net energy intake) by converting 70 ha of grassland to barley cultivation (based on lower contamination of grain compared to grass per unit of energy fed). 


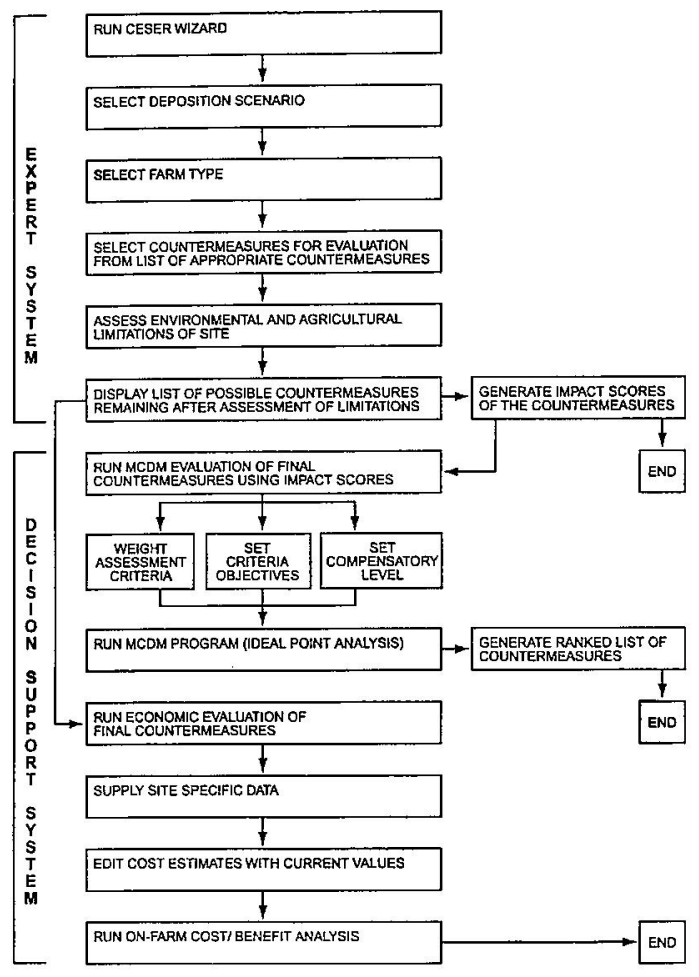

Figure 1. Countermeasure evaluation process
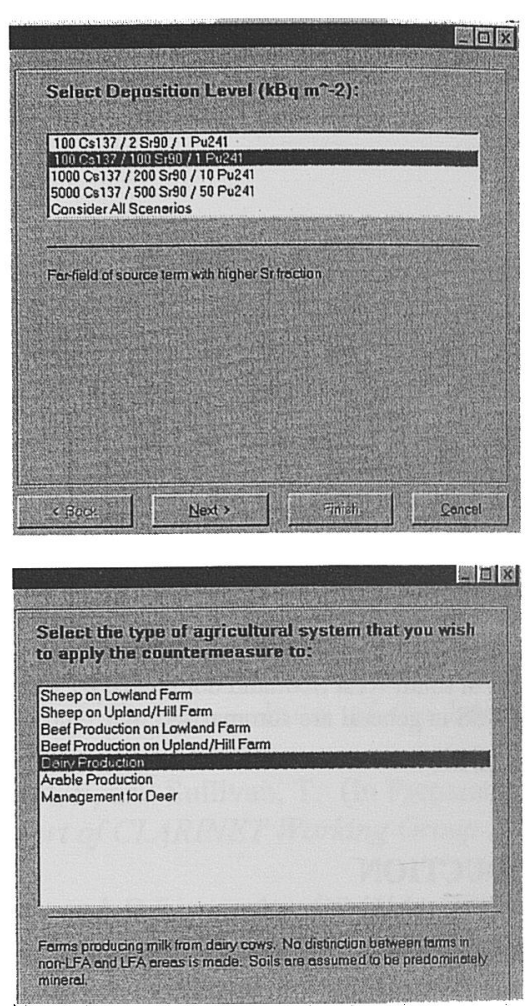

Figure 2. Selection of deposition level and farm type

To determine the suitability of each countermeasure for the dairy farm, the user has to provide information (Fig. 3), which is compared with pre-determined thresholds. In our example the environmental and agricultural conditions are not limiting. The suitable countermeasures are given scores for their potential environmental and agricultural impacts (Fig. 4). For the feeding of concentrate, some impact scores will vary according to the user input for the current percentage of concentrate fed $(0-24,25$ $49,50-65 \%$, above $65 \%$ the countermeasure is not worthwhile and would be dropped from the assessment).

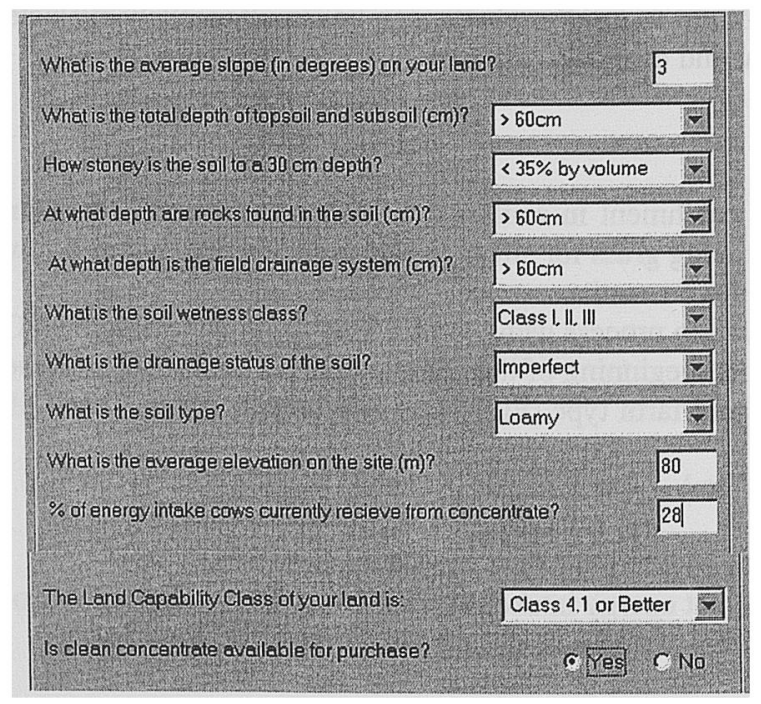

Figure 3. Assessment of limitations via user inputs 


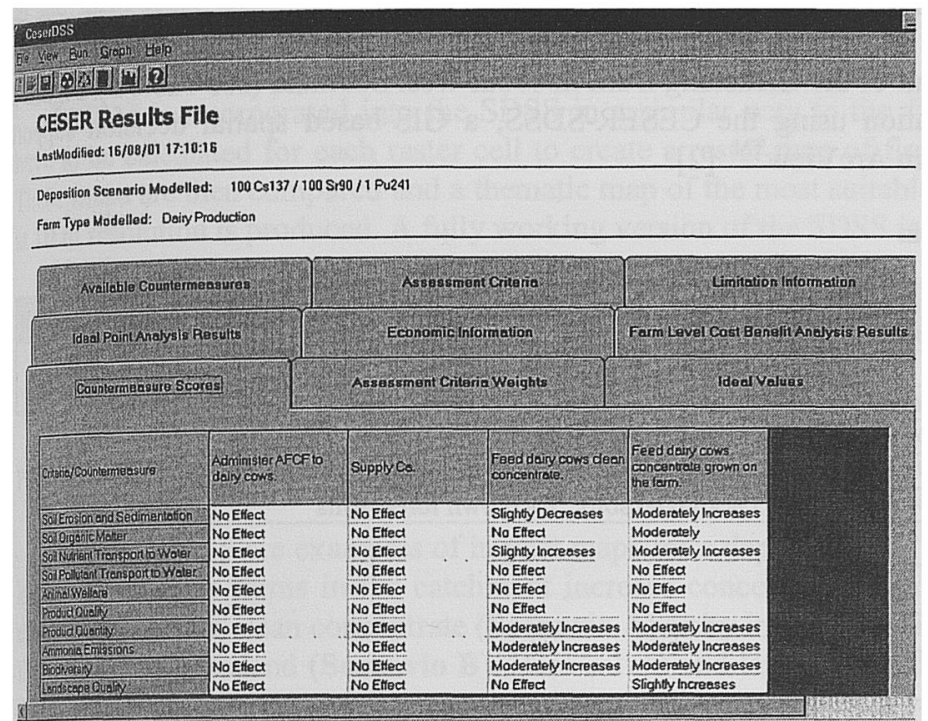

Figure 4. Matrix of impact scores for environmental/agricultural impacts

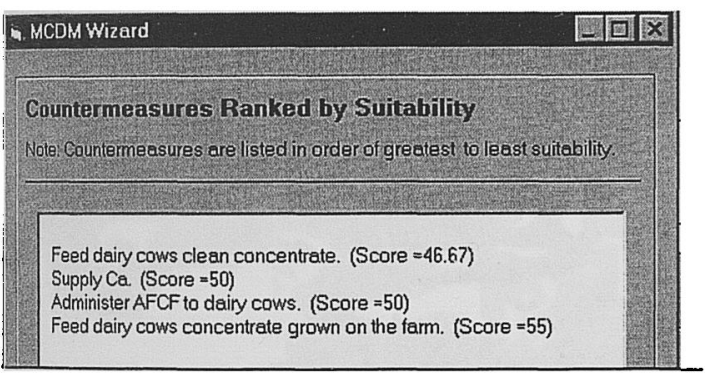

Figure 5. Outcome of the MCDM analysis, using the default settings for ideal objectives, weightings and compensatory level

The software uses Multicriteria Decision Making (MCDM) [3] to compare the impacts of the countermeasures and to enable the user to define ideal objectives and any weighting factors for each of the ten assessment criteria. The degree of compensation between poor performance on one or more criteria and good performance on others can be chosen. The final output is a list of countermeasures ranked from best (lowest score) to worst (highest score) (Fig. 5) based on their environmental and agricultural impacts. In addition an economic analysis can be undertaken [4] which calculates the on-farm costs and benefits of each countermeasure. Table 1 compares the results of the MCDM analysis with the cost-benefit analysis for the study farm [4].

Table 1. Costs of countermeasures, cost rankings and MCDM rankings for the dairy case study farm.

\begin{tabular}{|l|c|c|c|c|c|}
\hline $\begin{array}{l}\text { Deposition scenario } \\
{ }^{137} \mathrm{Cs} 100 \mathrm{kBq} \mathrm{m}^{-2},{ }^{90} \mathrm{Sr} 100 \mathrm{kBq} \\
\mathrm{m}^{-2}, \mathrm{Pu} 1 \mathrm{kBq} \mathrm{m}^{-2}\end{array}$ & $\begin{array}{c}\text { Net Farm } \\
\text { Cost } \\
\mathbf{E}\end{array}$ & $\begin{array}{c}\text { Environmental } \\
\text { Cost* } \\
\mathbf{f}\end{array}$ & $\begin{array}{c}\text { Total } \\
\text { Cost } \\
\mathbf{f}\end{array}$ & $\begin{array}{c}\text { Cost } \\
\text { ranking }\end{array}$ & $\begin{array}{c}\text { Multi-criteria } \\
\text { Ranking }\end{array}$ \\
\hline Administer AFCF & 1314 & 0 & 1314 & 2 & 2 \\
\hline Feed calcium & 684 & 0 & 684 & 1 & 2 \\
\hline Feed clean concentrate & 49844 & $-354^{* *}$ & 49490 & 4 & 1 \\
\hline Feed concentrate grown on farm & 4738 & $33637^{* *}$ & 38375 & 3 & 3 \\
\hline
\end{tabular}

"currently not included in the DSS software because a monetary value can only be estimated for few impacts * based on modelled changes in erosion and phosphorus loss 


\section{THE CATCHMENT SCALE APPROACH}

The case study area is the catchment of the Glenstang Burn in south-west Scotland (see Table 2). Figure 6 shows the countermeasure evaluation using the CESER-SDSS, a GIS-based spatial decision support system (SDSS), implemented within $\operatorname{ArcView}^{\mathrm{TM}}$ [2].

Table 2. Description of the study catchment

\begin{tabular}{|l|l|}
\hline Catchment size & $9 \mathrm{~km}^{2}$ \\
\hline Mean annual rainfall & $1256 \mathrm{~mm}$ \\
\hline Mean annual temperature & $7.7^{\circ} \mathrm{C}$ \\
\hline Median slope & 2 degrees \\
\hline Land use & $75 \%$ improved grassland, $19 \%$ arable \\
\hline Livestock units & 1275 (dairy cows, young beef cattle, sheep) \\
\hline Soil types & $80 \%$ gley soils, $15 \%$ alluvial soils, $5 \%$ brown forest soils \\
\hline
\end{tabular}

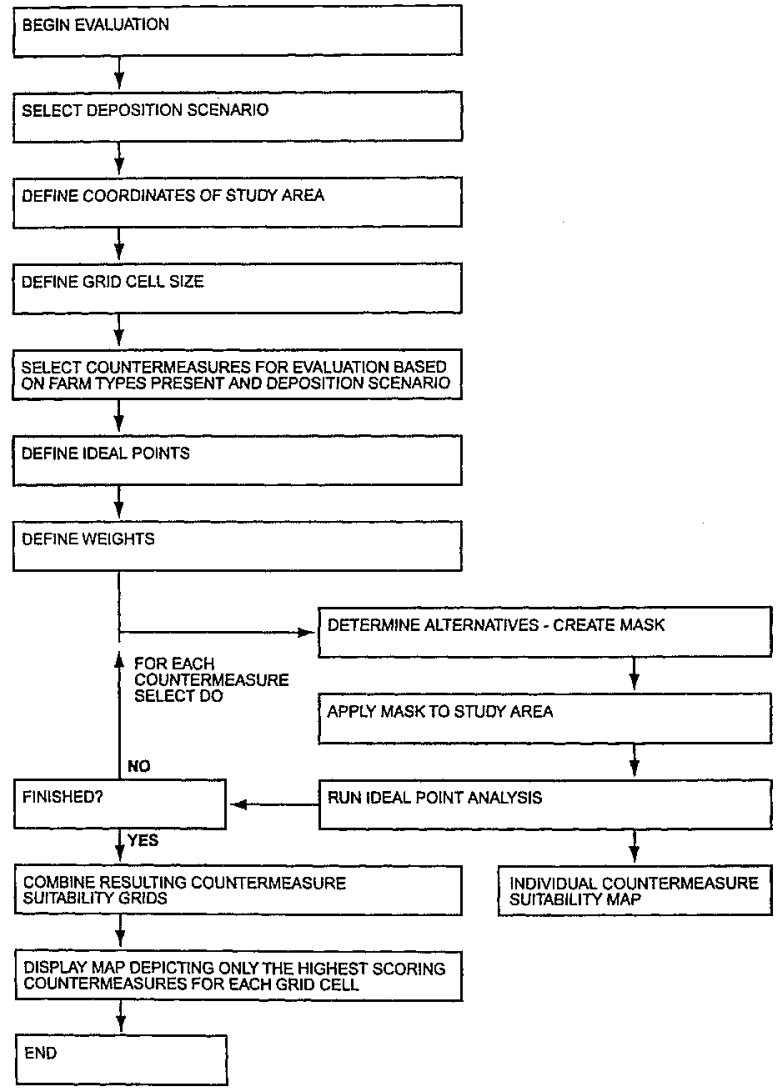

Figure 6. The CESER SDSS

The data requirements are:

Spatial data digital maps of soils, land cover and parish boundaries

digital elevation model

Non-spatial data minimum 10 years of daily rainfall, temperature and cloudiness

Soil properties and crop parameters

Agricultural census and land management data

Ammonia emissions inventory

The user has to select a radionuclide deposition scenario and the countermeasures to be assessed otherwise the required information on farm types, limitations etc resides in the system. Also stored in the system are maps for each countermeasure depicting the 'impact risk' for the same impact criteria as uscl 
in the farm-scale CESER-DSS (see Fig. 4). These maps are based on impact quantification through modelling (Fig. 8 \& 9) [5], calculations, experiments, contingent valuation and expert judgement, converted to a common impact scale (Fig.7).

MCDM is incorporated into the SDSS in a similar way to the farm-scale CESER-DSS, but scores have to be calculated for each raster cell to create a raster map of final scores for each countermeasure. These maps are then compared and a thematic map of the most suitable countermeasure for each grid cell at $10 \mathrm{~m}$ resolution is produced. A fully working version of the SDSS is not yet available.

\begin{tabular}{|c|c|c|c|c|c|c|}
\hline $\begin{array}{l}\text { Great } \\
\text { Decrease }\end{array}$ & $\begin{array}{l}\text { Moderate } \\
\text { Decrease }\end{array}$ & $\begin{array}{c}\text { Slight } \\
\text { Decrease }\end{array}$ & $\begin{array}{c}\text { No } \\
\text { Change }\end{array}$ & $\begin{array}{c}\text { Slight } \\
\text { Increase }\end{array}$ & $\begin{array}{l}\text { Moderate } \\
\text { Increase }\end{array}$ & $\begin{array}{c}\text { Great } \\
\text { Increase }\end{array}$ \\
\hline
\end{tabular}

$-1$

$-2 / 3$

$-1 / 3$

0

$+1 / 3$

$+2 / 3$

$+1$

Figure 7. Impact scale for farm and catchment-based assessments.

Figures 8 and 9 are examples of impact maps for a deposition of ${ }^{137} \mathrm{Cs},{ }^{90} \mathrm{Sr}$ and $\mathrm{Pu}$ at 100,100 and 1 $\mathrm{kBq} \mathrm{\textrm {m } ^ { - 2 }}$. All dairy farms in the catchment increase concentrate feeding from 28 to $80 \%$ of net energy, either by importing clean concentrate (Scenario $\mathbf{A}$ ) or by increasing barley production in the catchment at the expense of grassland (Scenario B). Beef calves and lambs are fattened on either imported or locally produced concentrate. The choice between Scenarios A and B will depend on soil types and other factors.

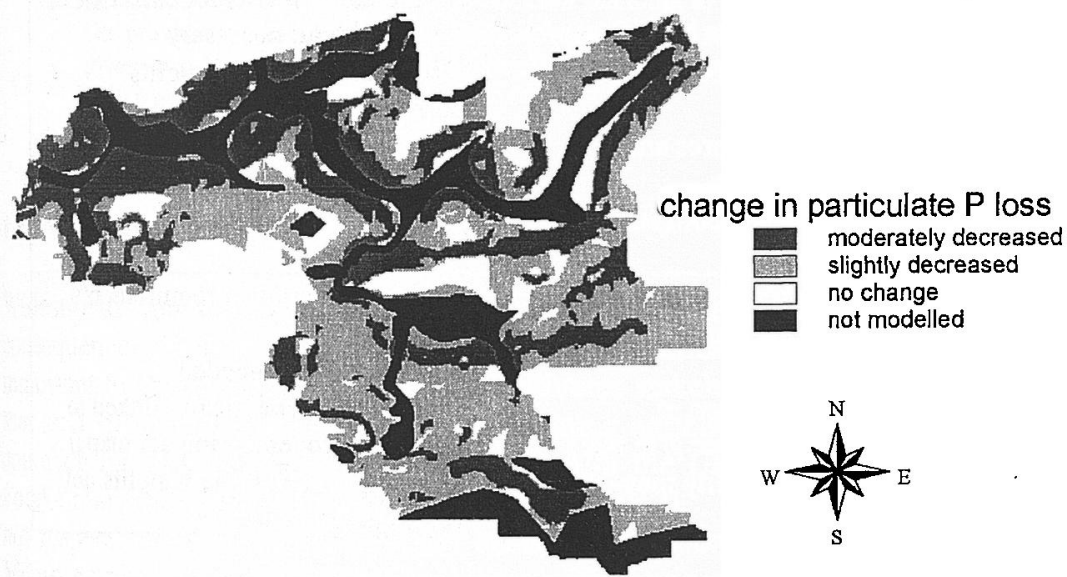

Figure 8. Predicted decrease in losses of particulate phosphorus due to decreased silage production in the catchment associated with the importation of clean concentrate (Scenario $\mathbf{A}$ ).

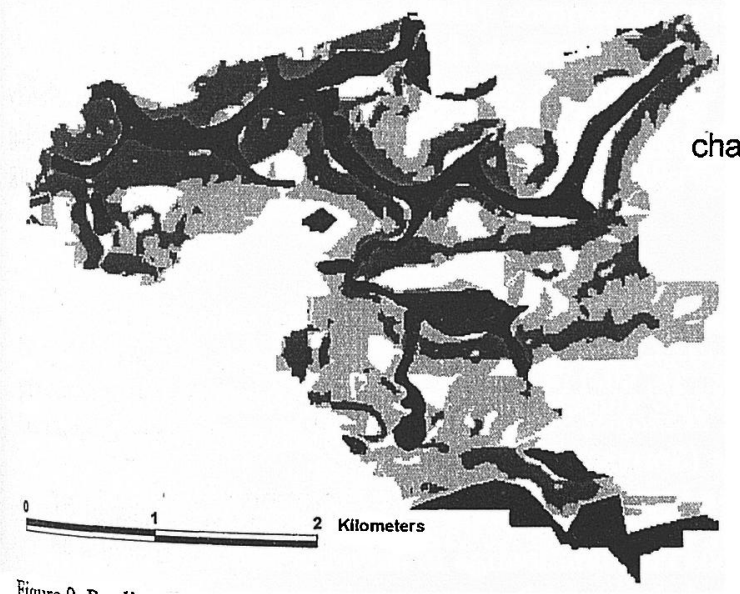

change in erosion

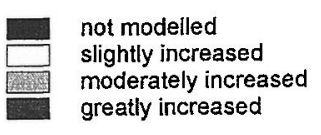

Figure 9. Predicted increase in erosion due to the increased production of barley in the catchment (Scenario B). 


\section{CONCLUSIONS}

The merits and limitations of the developed decision support systems are summarised in Table 3.

Table 3. Merits and limitations

\begin{tabular}{|c|c|c|}
\hline & Merits & Limitations \\
\hline Both DSS's & $\begin{array}{l}\text { - Formal assessment of countermeasures } \\
\text { using ten diverse environmental / } \\
\text { agricultural criteria } \\
\text { - Countermeasure selection restricted to } \\
\text { those suited for a specific combination } \\
\text { of radionuclide deposition and farm } \\
\text { type } \\
\text { - Exclusion of countermeasures not } \\
\text { suited to local conditions } \\
\text { - User may adjust degree of } \\
\text { compensation and ideal objectives and } \\
\text { apply weightings }\end{array}$ & $\begin{array}{l}\text { - Complex decision process has to be } \\
\text { simplified } \\
\text { - Significant subjective element } \\
\text { - Pre-set deposition levels and farm } \\
\text { types } \\
\text { - Site-specific prediction of food } \\
\text { contamination not included } \\
\text { - Impacts predicted with varying } \\
\text { degree of confidence } \\
\text { - No time - dependence included }\end{array}$ \\
\hline $\begin{array}{l}\text { Farm-scale } \\
\text { CeserDSS }\end{array}$ & $\begin{array}{l}\text { - Low technical/data requirements and } \\
\text { costs } \\
\text { - Easy use by non-specialists } \\
\text { - Results summarised as list of ranked } \\
\text { scores } \\
\text { - User can adjust impact scores and } \\
\text { default economic variables } \\
\text { - Costs and benefits can be compared } \\
\text { with MCDM rankings }\end{array}$ & $\begin{array}{l}\text { - Spatial variability not considered } \\
\text { - Single assessments for each type of } \\
\text { farm and land necessary } \\
\text { - Off-farm costs and benefits } \\
\text { currently not included }\end{array}$ \\
\hline $\begin{array}{l}\text { Catchment-scale } \\
\text { SDSS }\end{array}$ & $\begin{array}{l}\text { - Spatial variability taken into account } \\
\text { Large number of farms can be assessed } \\
\text { simultaneously } \\
\text { - Results summarised as maps of } \\
\text { optimum (lowest) scores per grid cell } \\
\text { - Option to generate suitability maps for } \\
\text { single countermeasures }\end{array}$ & $\begin{array}{l}\text { High technical/data requirements } \\
\text { and costs } \\
\text { - Specialist skills needed } \\
\text { - Models not dynamically linked to } \\
\text { GIS (pre-processed impact maps) } \\
\text { Mapping of costs and benefits not } \\
\text { yet included }\end{array}$ \\
\hline
\end{tabular}

\section{A copy of the CeserDSS (version 1.1.0) can be downloaded free of charge from http://www.stir.ac.uk/envsci/ceser/software.htm}

\section{Acknowledgements}

The CESER project was part-funded through the EU Fourth Framework / Nuclear Fission Safety Programme. Contributions from the Finnish Environment Institute (S. Rekolainen), the Nord-Troendelag College in Norway (H. Hansen), the University of Bremen (G. Kirchner) and the University of Salzburg (H. Lettner) are gratefully acknowledged.

\section{References}

[1] C.A. Salt, B. Rafferty, J. of Environ. Radioact., 56, 99-114. (2001)

[2] C.A. Salt, M. Culligan Dunsmore, J. Environ. Manage., 58, 169-178. (2000).

[3] M. Zeleny. Multiple Criteria Decision Making (Springer, New York, 1982)

[4] N.Hanley, C.A.Salt, M.D. Wilson, M. Culligan Dunsmore, J. Agric. Econ. (in press).

[5] S. Rekolainen, C.A. Salt, I. Bärlund, S. Tattari, M. Culligan Dunsmore, Water Air Soil Pollut.

(forthcoming). 